\title{
Government Expenditure and Quality of Education: A Case of Public Primary Schools in Kenya
}

\author{
Stephen Mutuku* ${ }^{\mathbb{C}}$, Julius Korir \\ Kenyatta University, Nairobi, Kenya \\ Email: *mutukus2002@yahoo.co.uk
}

How to cite this paper: Mutuku, S. and Korir, J. (2019) Government Expenditure and Quality of Education: A Case of Public Primary Schools in Kenya. Modern Economy, 10, 2405-2429.

https://doi.org/10.4236/me.2019.1012152

Received: November 7, 2019

Accepted: December 28, 2019

Published: December 31, 2019

Copyright $\odot 2019$ by author(s) and Scientific Research Publishing Inc. This work is licensed under the Creative Commons Attribution International License (CC BY 4.0).

http://creativecommons.org/licenses/by/4.0/

\begin{abstract}
Government allocation to primary education in Kenya has been provided since independence. The financing has been complemented by both community and household resources. The implementation of Free Primary Education (FPE) in 2003 increased enrolment to a Gross Enrolment Rate of 104 percent in 2003 from 92 percent in 2002 but stabilized at 104.2 percent in 2015. Class-pupil and teacher-pupil ratio increased to $45: 1$ and 56.6 between $2002 / 3$ and 2012/3 respectively which compromised the quality of education and school effectiveness. This was due to teachers concentrating on the Kenya Certificate of Primary Education (KCPE) examinations results at the expense of skill acquisition in arithmetic and comprehension. The compromise produced biased KCPE results that could affect key policy decisions made based on the results. Despite increased enrolment that affected class-pupil and pupil-teacher ratio, 35 percent of households' expenditure to education before FPE implementation was saved with the introduction of FPE. In the past, the measure of education quality has been KCPE results which were mostly biased. The KCPE results were low with FPE despite increased government expenditure on education. Although FPE benefits seemed high, questions on actual impact of government expenditure on overall school performance measured by education quality levels had not been addressed before, during and after the FPE implementation and they form the problem discussed in the study. Analysis results revealed that government expenditure had positive and statistically significant impact on enrolment and quality of education Coefficients for school characteristics such as number of classes, teachers, books and availability of toilets had positive and at least 95\% - 99\% statistical significance with government expenditure. Further, coefficients for class types and schools located in rural areas were found to affect enrolment at $99 \%$ statistical significance. Further, education quality was low in 2004 as compared
\end{abstract}


to 2000 but improved in 2012 compared to 2004. Class-pupil \& pupil-toilet ratio, distance from small town, dispensary, bookshop, and secondary school, as well as class type, contributed negatively to efficiency scores. Class-book ratio, government expenditure, playfield availability, and class numbers contributed to the inefficiency levels identified. On policy, it was clear that the government should increase expenditure on education which affected overall school performance in public primary schools. The expenditure should be increased towards quality classes and teachers who are high determinants of education quality.

\section{Keywords}

Quality of Education, Government Expenditure, Primary Schools

\section{Introduction}

Human capital integrates conscious, continuous and acquisition processes for requisite knowledge, education, skills, and experience. The level of human capital is cultivated by the quality of education that contributes to a country's economic and political growth development [1] [2] [3] [4]. Various studies found quality of education to have significant and positive relationship with schooling benefits and economic growth financed by both government, household and community expenditures within various policies aimed at achieving non-excludable and non-rival education benefits [5] [6] [7] [8].

\subsection{Evolution of Policies Guiding Primary Education in Kenya}

Policies guiding the education sector evolved since independence with over six commissions and committees established to review or develop education policies that will lead to developing self-expression, discipline and self-reliance in an all-round educational experience for learners. The latest commission was tasked to review the 8-4-4-education system and proposed the 2-6-6-3 education framework that was rolled out in 2017/8 with much emphasis on the level of education [9]-[21].

Across the years, the policies developed were geared towards achieving the Educational for All (EFA) and Universal Primary Education (UPE) framework which targets a 100 percent gross enrolment rate. In 2003, the country implemented the Free Primary Education (FPE) in line with the EFA and UPE fast track Millennium Development Goals (MDG) number 2 and Sustainable Development Goals (SDGs) number 4 on "ensuring inclusive and equitable quality education and promote lifelong learning opportunities" as well as facilitate achievement of 100 percent (UPE) for school-going age.

Various studies showed that very little had been done to establish the impact of government expenditure on other school performance indicators especially the quality of education despite increased enrolment with FPE and increasing 
government allocation to education as presented in Figure 1 education [22] [23] [24] [25].

\subsection{Trends in Financing Public Primary Education in Kenya}

Government financing towards the education system started in the 1970s through the Harambee education programme for standard one to four. This was followed by the cost-sharing Structural Adjustment Programme (SAPs) period in the 1980s. The SAP financing framework increased household's contribution to an average of 35 percent of the total education costs in school costs in public schools. This led to low enrolment, high dropouts, grade repetition, low completion, and poor transition rates, hence inefficiencies in resource utilization. The FPE implementation in 2003 sought to address the cost-sharing/SAP effects though with more concerns over the quality of education. During the time, the budget alocation increased from 6.2 percent of the proportion of the Gross Domestic Product (GDP) in 2002/03 to 7.4 percent in 2005/06. It, however, dropped to 5.3 percent in $2014 / 15$ and further to 5.24 in $2017 / 18$. As a result, Gross Enrolment Rate rose to 104 percent in 2003 from 92 percent in 2002 and further rose to 105.3 percent in 2017. As a consequence, pupil-teacher and pupil-class ratios increased from 36:1 and 42:1 to 45:1 and 57:1 between 2002/03 and 2012/03 and further 42:1 and 55:1 in 2017, respectively. Despite the increased expenditure on the education sector by the government, the changes in levels of enrolment were not in tandem with the trends of increased government expenditures, further, these in enrolment further compromised the education quality and schools' levels of technical efficiency were compromised [16] [17] [18] [19] [22] [23] [26] [27]. The government allocation to the education sector is presented in Figure 1.

From Figure 1, with the introduction of FPE in 2002/3, the Ministry of

\section{$\%$ change in ministry allocation, primary school allocation and school enrolment}

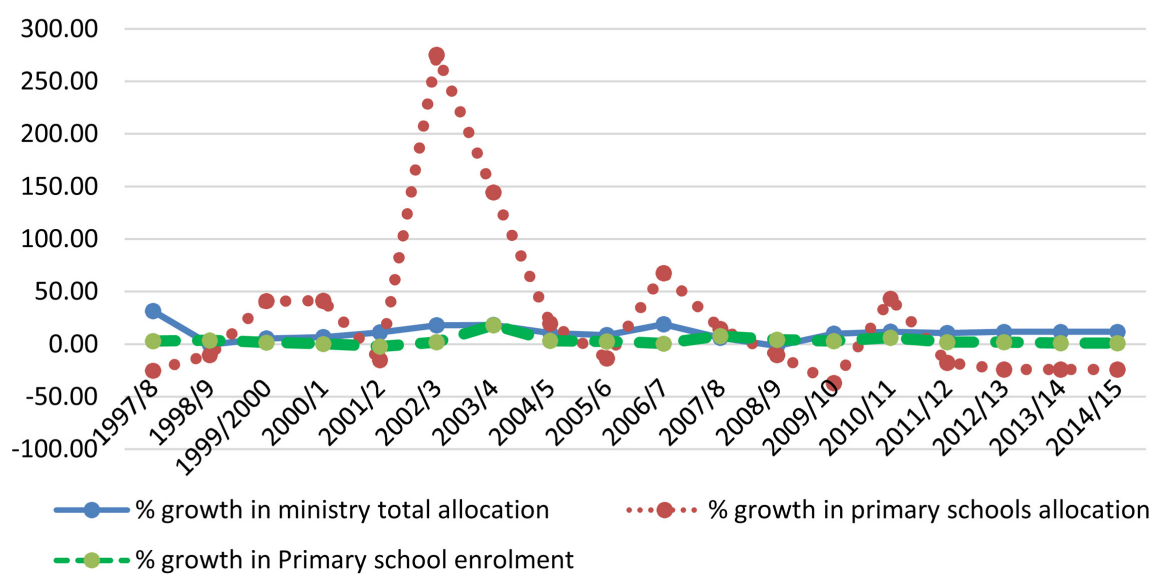

Figure 1. Percentage growth in ministry of education allocation, primary education allocation and school enrolment, Source: Republic of Kenya, 1998-2015. 
Education allocation to primary education increased by 275.22 percent in 2002/3 reducing by 144.37 percent in 2003/4 and low of 19.55 percent in 2004/5 respectively, though the trend had irregular budgetary allocations until 2014/5 [22] [26] [27].

\subsection{Quality of Education in Primary Education}

Policies developed by various commissions and committees emphasized highlighted the need for enhanced performance in Kenya's primary schools related to quality of education [12]-[21]. However, there were various notables limitations related to school performance that had been identified from previous studies that evaluated primary education performance based on overall school enrolment and KCPE results rather than overall quality of education [5] [20] [27] [28].

Measurement of education quality was for a long time pegged on KCPE examinations scores in line with various policies [12]-[21]. An analysis of KCPE scores and the relationship to growth in candidature had marginal changes when compared to changes in budgetary allocation to primary education as compared in Figure 1 and Figure 2.

Further, the effect of enrolment of pupil-class and pupil-class ratio are presented in Figure 3.

The effect of increased enrolment on pupil-teacher and pupil-class ratio presented in Figure 3 created an environment where teachers were constrained to deliver the curriculum on a result basis [27] [29] [30]. Other than KCPE measurement of quality of education, two independent assessments that included; the Monitoring Learning Achievement in Lower Primary (MALP) which carried out assessment in class 2 and South African Consortium for Monitoring Education

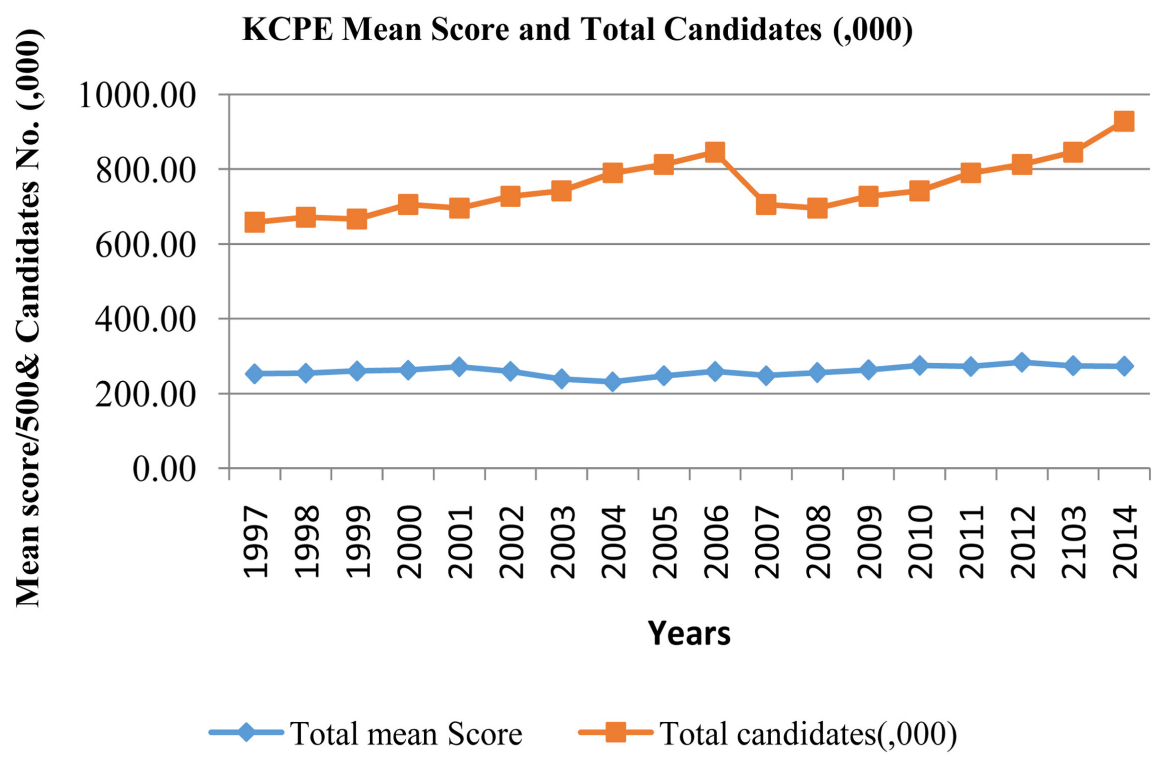

Figure 2. Total mean KCPE scores and total candidates $(, 000)$, Source: Kenya national examinations council, 1998-2015. 


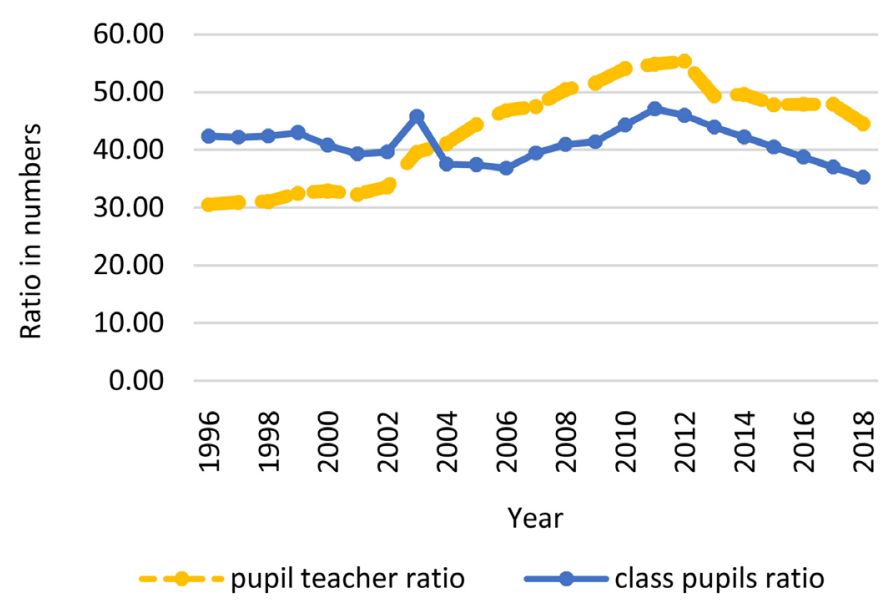

Figure 3. Pupil-teacher and pupil-class ratio ratio; Source of data: statistical abstracts, 2005; 2010; 2012b; 2017.

Quality (SACMEQ) to assess class 6 pupils were undertaken respectively were also used to evaluate education quality. SACMQE mean scores from three assessments are presented in Table 1.

The class 6 SACMEQ scores shown in Table 1 supported by Klee's [31] and Musyoka [32] who argued that in a controlled environment where education variables are equally comparable to all students, pupils perform in every bit as well irrespective of school location and related households differences. Further, variation in scores was attributed to the fact that urban public primary schools have a much more advantaged student body and work on the contusive environment which has had more learning opportunities from birth. The truth in this assertion has not been established and thus remain a critical hypothesis for empirical justification this study.

\subsection{Purpose of the Study}

Despite government's determination to achieve Universal Primary Education through overall financing under FPE, the performance measure of the quality of education by KCPE scores has been biased resulting from targeted teaching and examination malpractices in most schools which did not clearly explain the impact of FPE financing and quality of education. This was despite high enrolment, high pupil-class, and pupil-teacher ratio [27] [29].

The randomly sampled class six scores from the SACMEQ evaluation process under UNESCO [33] were collected from unbiased environment and thus used as the key measure of pupil acquisition and level of education quality; a factor not instituted in KCPE results.

\subsection{Data Source, Scope, and Analysis}

Secondary data collected from the United Nations Education, Scientific and Cultural Organization (UNESCO) [33] - the Southern and Eastern Africa Consortium for Monitoring Educational Quality (SACMEQ) I, II and III for the 
Table 1. Class 6 SACMEQ assessment scores.

\begin{tabular}{ccccc}
\hline Year & Assessment & $\begin{array}{c}\text { Mean score/500 } \\
\text { (Reading) }\end{array}$ & $\begin{array}{c}\text { Mean score/500 } \\
\text { (Arithmetic) }\end{array}$ & $\begin{array}{c}\text { Total pupils } \\
\text { examined }\end{array}$ \\
\hline 1997 & SACMEQ I & 344.0 & 346.9 & 3233 \\
2004 & SACMEQ II & 346.5 & 353.9 & 3296 \\
2007 & SACMEQ III & 343.1 & 351.9 & 4145 \\
\hline
\end{tabular}

Source: SACMEQ, 1997, 2004, 2007.

years 2000, 2004 and 2012. SACMEQ IV data have not been released for use hence once published will be applied in enhanced research. Data on government expenditure was collected from Statistical Abstracts for the year 1996/7 to 2014/15 using a school-based cross-section survey covering the 8 regions were also used in this study. The data sampled included variables explaining pupil characteristics, teacher characteristics and school-based characteristics as well as teacher and household characteristics. The relevant variables specific to the study were extracted from the data set, coded and applied in analysis using STATA statistical package.

\section{Reviewed Literature}

\section{Human Capital Theory}

The human capital theory started with the work of classical authors Adam Smith [34] and Alfred Marshal [35]. Adam Smith [34] concluded that a man educated at the experience of labor and time may be compared to one of the experienced machines in a production environment. In addition, Alfred Marshal [35] and Earle [36] referred industrial training as a national investment that involves costs and time which can be used to evaluate the quality of human capital acquired [36].

The human capital acquired integrates social capabilities which complementarily reference quality of education leading to economic growth. Though growth may be unbalanced if innovation and quality of education are provided; the growth patterns are thus heterogeneous depending on the quality of institutions providing education [37] [38] [39].

Proponents of human capital theory argue that education spending should be expanded to the point where the rate of return to additional spending to education was equal to the general rate of return of capital, thus the knowledge and skills acquired can be used to qualify labor quality in a productive environment [40] [41]. To achieve the functions associated with human capital development, the investment in an education program includes current income which may generate both monetary and non-monetary returns on investment in future [42]. Although human capital is highly studied, its deficiencies go to the heart of neoclassical economics. In some instances, Block [43], Zhu and Li [38] and Marginson [44] argued that the theory was based on the argument that all human-behavior was based on the economic self-interest of individuals operating 
freely with competitive markets. These forms of personal interest and related human treatment distorted the model and thus education contributed to differences in earnings between people and only in verifiable circumstances [39] [45].

The human capital model as expressed by Becker and Tomes [46] [47] related to the incomes generated from physical capital expressed as:

$$
y(i, t)=h(i, t) w(i, t)+a(i, t) r(i, t)
$$

where

$h(i, t)$ is the level of human capital for $i$ pupils it time $t$.

$w(i, t)$ and $r(i, t)$ are the wage rates and return in the assets respectively.

Building on this work, the framework provided by Ashenfetter and Krueger [42], Block [43], Marginson [44] and Becker [45] provide evidence of the contribution of human capital to the evolution of income distribution within financial market imperfections. Expenditures on education help grow human capital across a given generation expressed as:

$$
h(i, t)=h[e(i, t), s(i, t)]
$$

where

$e(i, t)$ is the level of accumulated quality of education.

$s(i, t)$ is the expenditures made to schooling for a student to achieve human capital accumulations.

The schooling environment where students attend so as to acquire human capital provides a complementarity between quality and expenditures made expressed $\frac{\partial^{2} h}{\partial e \partial s}>0$. From the equation, the capacity and levels of human capital acquired are specified as:

$$
e(i, t)=\rho e(i, t-1)+\varepsilon(i, t)
$$

where

$0 \leq \rho<1$ and $\varepsilon(i, t)$ are the random components of quality of education acquired respectively.

The levels of education in the process are determined by various indicators related to school location, quality of teachers and the variables assumed in a school environment have been studied by the following authors presented in Table 2.

A study by Sunder \& Vischer [39] used the Cobb-Douglas production function to establish human capital and growth specification found that human capital plays a positive role in per capita GDP growth in the presence of better economic opportunities and high-quality legal institutions. Economic opportunities reinforce the effect of human capital on growth. The results found that human capital is likely to be underestimated in empirical specifications that do not account for both channels. There exist complements alternative explanation for the weak growth effects of human capital based on outlier observations and measurement issues. 
Table 2. Empirical literature reviewed.

\begin{tabular}{|c|c|c|c|}
\hline Author & Study title & Methodology & Results \\
\hline $\begin{array}{l}\text { Mizala \& } \\
\text { Romaguera } \\
{[48]}\end{array}$ & $\begin{array}{l}\text { School } \\
\text { performance } \\
\text { and Choice: } \\
\text { The children } \\
\text { Experience }\end{array}$ & $\begin{array}{l}\text { OLS and } \\
\text { TSLS }\end{array}$ & $\begin{array}{l}\text { - Incentives by the voucher system are } \\
\text { akin to public rather than private schools } \\
\text { in the Chilean education system } \\
\text { - The parents' education did not relate } \\
\text { positively to the child's performance } \\
\text { because it was facilitated by the } \\
\text { voucher system } \\
\text { Despite the fact that government funding } \\
\text { to households depended on school type, } \\
\text { test scores gained were more equal } \\
\text { among children from households } \\
\text { of all socio-economic classes }\end{array}$ \\
\hline $\begin{array}{l}\text { Cameron } \\
\text { and } \\
\text { Heckman } \\
{[49]}\end{array}$ & $\begin{array}{l}\text { The } \\
\text { Dynamics of } \\
\text { educational } \\
\text { attainment } \\
\text { for Black, } \\
\text { Hispanic and } \\
\text { White } \\
\text { males }\end{array}$ & $\begin{array}{l}\text { Ordered } \\
\text { choice model } \\
\text { (outcomes } \\
\text { depended on } \\
\text { innate } \\
\text { capacity and } \\
\text { household } \\
\text { background } \\
\text { factors. }\end{array}$ & $\begin{array}{l}\text { - From the analysis, the Intelligence } \\
\text { Quotient (IQ) type test scores were } \\
\text { used as a control variable for the } \\
\text { ability of knowledge achieved vis-a-vis } \\
\text { level of investment } \\
\text { - Coefficients for the two control variables } \\
\text { had a significant effect on the inmates' } \\
\text { educational attainment } \\
\text { Educational investment ratios with } \\
\text { respect to school type and race were not } \\
\text { factored in the model which was a } \\
\text { verifiable gap, thus could not establish } \\
\text { whether differentiated race and } \\
\text { government investment had any effect on } \\
\text { the scores attained among the inmates }\end{array}$ \\
\hline $\begin{array}{l}\text { Abt } \\
\text { Associates } \\
{[50]}\end{array}$ & $\begin{array}{l}\text { Evaluation of } \\
\text { the expanded } \\
\text { learning time } \\
\text { initiatives }\end{array}$ & $\begin{array}{l}\text { linear } \\
\text { regression } \\
\text { models }\end{array}$ & $\begin{array}{l}\text { Quality of education was depended on } \\
\text { school inputs such as teacher } \\
\text { characteristics and student } \\
\text { socio-economic characteristics } \\
\text { respectively } \\
\text { - The study did not provide a clear } \\
\text { relationship between households' } \\
\text { socio-economic characteristics as } \\
\text { well as children's education results }\end{array}$ \\
\hline $\begin{array}{l}\text { Bold, et al., } \\
{[22]}\end{array}$ & $\begin{array}{l}\text { Why did } \\
\text { abolishing } \\
\text { fees not } \\
\text { increase } \\
\text { public school } \\
\text { enrolment in } \\
\text { Kenya }\end{array}$ & OLS & $\begin{array}{l}\text { - Demand for education especially in } \\
\text { public schools increased with the } \\
\text { introduction of incentives programmes } \\
\text { - } \text { Quality of education in Kenya schools } \\
\text { was based on KCPE results which were } \\
\text { poor compared to increasing enrolment } \\
\text { rate and attitude of school administrators } \\
\text { The study included household income } \\
\text { and not government expenditure on } \\
\text { enrolment and quality of education }\end{array}$ \\
\hline
\end{tabular}

In summary, there exists a significant relationship between government expenditure, household characteristics and school characteristics to education quality. However, school location could in one way affect education quality with a quality gap exhibited by the differentiated learning environments that resulted 
in varied scores in relation to government expenditure before and after FPE implementation.

\section{Methodology}

\subsection{Human Capital Theory, Government Expenditure and Quality of Education}

The adoption of human capital theory in education takes an altruistic set up where parents care about the present educational consumption and current leisure of their children [51] [52]. The number of children in a household attending school is taken as given thus, to allow for simplicity of exposition it's normalized to 1 [53].

The model assumes that children spent part of their time in leisure $h_{l}$ which is flexible and therefore treats them as a continuous choice variable thus taking the form:

$$
H=h\left(h_{l} ; h_{s}\right) \text { where } \frac{\partial H}{\partial h_{l}}<0
$$

In a school setting, this is a utility from the production function defined over the current consumption by children enrolled in schools, the current leisure enjoyed by children and levels of human capital achieved. When related to household contribution in its acquisition, the current household consumption $c_{1}$ is given by:

$$
c_{1 s}=y+w h_{l}-q
$$

where

$y$ is the expenditures on education.

$h_{l}$ are the hours of leisure.

$w$ is the cost of hours of leisure assumed as wage.

$q$ is the direct cost of education.

Relating Equations (3) and (4), the quality of education achieved is equated to the sums of human capital accumulation defined by the knowledge acquired by learners enrolled in a given school and expressed as:

$$
c_{2 s}=K+H
$$

where

$K$ is the exogenous endowment of human capital.

$H$ is defined in Equation (3).

Therefore, school environment facilitates human skill acquisition such as the provision of playing field also attach value to leisure enjoyed by learners enrolled in a given school expressed as:

$$
L=1-h_{s}-h_{l}
$$

where $L$ and time are normalized to 1 .

The parents' choice for learner enrolment of $h_{l}$ (in a situation where children are in school) is given as: 


$$
\max \left[\mu_{s}^{*}\left(h_{l}\right), \mu_{l}^{*}\left(h_{l}\right)\right]
$$

where

$$
u_{s}^{*}=\max _{h_{l}} u\left(y+w h_{l}-q, K+H\left(h_{l} ; h_{s}\right), 1-h_{s}-h_{l} ; M\right)
$$

The expression in equation 8 shows that at this point $\mu$ is regarded as the amount of human capital acquired expressed in terms of test scores. Therefore the scores acquired are expressed as:

$$
\text { Scores }_{l}^{*}=\max _{\text {scores }_{h_{l}}}\left(y+w h_{l}-K, 1-h_{l} ; M\right)
$$

where $M$ represent characteristics related to the quality of education acquired. Teacher education and experience and school characteristics among others.

\subsection{Model Specification}

Following Taylor et al. [54] and Kings et al. [55], student achievement is a function of endogenous school inputs (family background, school characteristics, physical characteristics, and school enrolment) and a function of exogenous educational environment.

From Equation (9), and adopting Taylor et al. [54], Kings et al. [55] and Hanushek [51], this study relates the models to Todd and Wolpin (2003) and Rugiero [53] model where the human capital function is determined by score acquired expressed as:

$$
\text { Scores }_{l}^{*}=\max _{\text {scores }_{h_{l}}}\left(y+w h_{l}-K, 1-h_{l} ; M\right)
$$

The framework presented in Equation (10) adopts various variables such as pupil characteristics, school characteristics and government expenditure as independent variables determining score levels to have:

$$
\text { Score }_{i j t}=c+\sum_{k=1}^{N_{x}} \alpha_{k} x_{k}+\beta_{1} z_{j t}+\beta_{2} Y_{j t}+X_{j t}+\sum_{t=1997,2004,2007} D_{t}+\varepsilon_{i j t}
$$

where

$i, j, t$ are indices for total pupil $i$, enrolled in school $j$ at time $t$.

$N_{x}$ is the number of schools that explained as the control variable $x$.

$X_{t}$ is the school observable school characteristics.

$Z_{j t}$ is the Pupil and Teacher related characteristics.

$Y_{j t}$ is the government expenditure.

$D_{t}$ are dummies for 2000, 2004 and 2012.

Equation (11) is improved to include the stock of human capital expressed as aggregated school scores $($ score $=S$ ) in arithmetic and reading for different schools located in different regions. The schools have specific variables that determine the various scores estimating the model as:

$$
S_{j t k}=\alpha+X_{j t}^{d} \gamma+X_{j t}^{s} \mu+\epsilon_{j t k}: t=1,2,3, k=1,2
$$

where

$S_{j t k}=$ the average score on the class six SACMEQ test on arithmetic and 
comprehension, $k$ for school $j$ in year $t$.

$X_{j t}^{d}=$ specific observable variables for school $i$ in year $t$ that include the number of classes, number of toilets, availability of playfield, number of textbooks, school possession index, location of the school and class types.

$X_{j t}^{s}=$ school-specific variables for school $j$ in year $t$.

$\gamma$ and $\mu$ are vectors of parameters to be estimated, $\alpha$ is the intercept and $\epsilon$ is an iid disturbance term.

\subsection{Estimation of the Model}

The framework by Coates, Hamish, and Rothman [56], Ferguson and Ladd [57] and Ladd, Roselius, and Walsh [58] were used to develop the model relationship between the expected school performance and various characteristics presented as:

$$
S_{j t k}=\alpha+X_{j t}^{d} \gamma+X_{j t}^{s} \mu+Z_{j t} \beta+\left(Z_{j t} * X_{j t}\right) \delta+\left(E_{j t} * X_{j t}\right) \phi+\epsilon_{j t k} .
$$

Equation (14) ensured ad-hoc variable inclusion and understanding thus the relationship between government expenditure and quality of education. The study adopts a log-linear model given that all observations are positive (McGraw, 1995) presented in Equation (14) written as:

$$
\begin{aligned}
\ln S_{j t k}= & \alpha+d \ln X_{j t} \gamma+s \ln X_{j t} \mu+\ln Z_{j t} \beta+\ln \left(Z_{j t} * X_{j t}\right) \delta \\
& +\ln \left(E_{j t} * X_{j t}\right) \phi+\epsilon_{j t k}
\end{aligned}
$$

where

$Z_{i(t), t}=$ a vector of observable variables including pupil and teacher characteristics that include pupil-teacher ratio, pupil-class ratio, pupil-book ratio, pupil-toilet ratio, teacher experience, and teacher absenteeism, presented as:

$$
X_{j t}=\left(X_{j t}^{d}, X_{j t}^{s}\right)
$$

Which explains variables defined in Equations (14)-(16).

With the adoption of the model explained in Equation (15), the equation assumed that the parameter vector $\beta$ is closely related to scores with a positive sign and the vector parameter $\delta$ and $\varphi$ captures interaction effects during analysis.

Estimation of cross-section panel data outlining the effect of government expenditure on quality expenditure is presented in Table A1.

\subsection{Data Limitation and Data Analysis}

The study used datasets for the years 2000, 2004 and 2012. These data sets were not as recent but were the current data that had been undertaken in the country. The SACMEQ IV, 2018 had not been released during the time of this study; hence provides a critical area of further studies when the data set has been released.

In addition, Model specification tests were carried out, though several limitations that included potential selection bias, potential endogeneity, and poten- 
tial unobserved heterogeneity were experienced and corrected using Olsen (1980)-Ordinary Least Squares (OLS) and Terza, Basu and Rathmouz [59] Two-Stage Residual-Inclusion (TSRI) method. In addition, data, robustness was tested using pedagogical cohorts or a sample that would be more motivated for over or underestimation of the effort to use the data. Further, panel data estimation took-in-to consideration heterogeneity of individual cross-section units occasioned by allowing for individual specific fixed effects that gave more variability and degrees of freedom.

\section{Empirical Findings}

\subsection{Descriptive Analysis}

The study sampled 174,173 and 181 schools for the years 2000, 2004 and 2012 with means and standard deviations presented in Table A2 while the mean government expenditure per region was presented in Table A3. The school performance measure for quality of education was determined by the test scores achieved in arithmetic and reading analysed from the SACMEQ reports presented in Table A4. The various school locations, school distance from social amenities, school characteristics, class types, and teacher numbers are presented in Tables A5-A10 respectively.

\subsection{Regression Results for the Effect of Government Expenditure on Quality of Education}

The analysis used Haussmann tests to verify the use of Fixed Effects (FE) or Random Effects (RE) that helped undertake the regression analysis on the effect of government expenditure on quality of education given school characteristics presented in Table 3.

\subsection{Results for Diagnostic Tests for Fixed Effects and Random Effects for the Pseudo-Panel Analysis}

The Haussmann test on the xtreg fixed and random effect models (see Table A10 and Table A11), Prob > chi2 $=0.045$ and chi2 (16) $=(b-B)^{\prime}\left[\left(V \_b-V \_B\right) \wedge\right.$ $(-1)](b-B)=2.14 \mathrm{e}-20$ was achieved. Given that $0.045<0.05$, then, the unique errors (ui) were uncorrelated with the regressors, and therefore the null hypothesis was rejected, thus, the regression analysis adopted fixed-effect analysis for objectives one and two (Greene, 2010; Williams, 2015).

The regression analysis using the fixed-effect model is presented in Figure 3.

The coefficients for pupil-book ratio, pupil-toilet ratio were related to Hanushek [51] and Greenwald, Hedges and Laine [60] who concluded that estimates on school performance had no significant effect when teacher/student ratio, teacher education, experience, and salary and government expenditure per student on the final test scores were correlated. In this case, the evaluations were conditioned and had a high probability of bias. Further, coefficients for availability of playfield and quality of education in the selected schools agreed with 
Table 3. Effect of government expenditure on quality of education given school characteristics.

\begin{tabular}{|c|c|c|c|c|c|c|}
\hline \multicolumn{7}{|c|}{ Multivariate Regression Analysis } \\
\hline Variables & $\begin{array}{l}\text { Arithmetic } \\
\text { score } 2000\end{array}$ & $\begin{array}{l}\text { Arithmetic } \\
\text { score } 2004\end{array}$ & $\begin{array}{l}\text { Arithmetic } \\
\text { score } 2012\end{array}$ & $\begin{array}{c}\text { reading score } \\
2000\end{array}$ & $\begin{array}{c}\text { reading Score } \\
2004\end{array}$ & $\begin{array}{c}\text { reading } \\
\text { Score } 2012\end{array}$ \\
\hline $\begin{array}{l}\text { Government } \\
\text { Expenditure }\end{array}$ & $\begin{array}{c}-12.53^{\star * \star} \\
(7.00)\end{array}$ & $\begin{array}{c}-51.69^{* * *} \\
(10.52)\end{array}$ & $\begin{array}{c}-48.49^{* * *} \\
(14.12)\end{array}$ & $\begin{array}{c}-94.41^{\star * \star} \\
(11.19)\end{array}$ & $\begin{array}{c}-63.8^{\star * *} \\
(12.11)\end{array}$ & $\begin{array}{c}-73.7^{* * *} \\
(15.31)\end{array}$ \\
\hline \multicolumn{7}{|c|}{ School characteristics } \\
\hline $\begin{array}{l}\text { Pupil-book } \\
\text { ratio }\end{array}$ & $\begin{array}{l}0.0337^{\star *} \\
(0.0138)\end{array}$ & $\begin{array}{c}0.0037 \\
(0.00516)\end{array}$ & $\begin{array}{c}0.0068^{\star *} \\
(0.00336)\end{array}$ & $\begin{array}{l}0.0349^{* *} \\
(0.00145)\end{array}$ & $\begin{array}{l}0.00747 \\
(0.0062)\end{array}$ & $\begin{array}{l}0.007^{\star *} \\
(0.0041)\end{array}$ \\
\hline $\begin{array}{l}\text { Pupil -toilet } \\
\text { ratio }\end{array}$ & $\begin{array}{c}-0.479^{* * *} \\
(0.155)\end{array}$ & $\begin{array}{c}-0.102^{*} \\
(0.054)\end{array}$ & $\begin{array}{l}-0.023 \\
(0.065)\end{array}$ & $\begin{array}{c}-0.001^{* * *} \\
(0.0003)\end{array}$ & $\begin{array}{c}-5.069^{* *} \\
(2.996)\end{array}$ & $\begin{array}{l}-0.15^{* * *} \\
(0.0718)\end{array}$ \\
\hline $\begin{array}{c}\text { Availability of } \\
\text { playfield }\end{array}$ & $\begin{array}{c}0.0968 \\
(0.0911)\end{array}$ & $\begin{array}{l}-0.14^{* *} \\
(0.061)\end{array}$ & $0(0)$ & $\begin{array}{c}0.11 \\
(0.092)\end{array}$ & $\begin{array}{c}-0.15^{* * *} \\
(0.055)\end{array}$ & $\begin{array}{c}0 \\
(0)\end{array}$ \\
\hline $\begin{array}{l}\text { Pupil-class } \\
\text { ratio }\end{array}$ & $\begin{array}{l}2.03^{* * *} \\
(2.379)\end{array}$ & $\begin{array}{c}0.00039 \\
(0.003)\end{array}$ & $\begin{array}{l}0.00098 \\
(0.0066)\end{array}$ & $\begin{array}{l}4.76^{* * *} \\
(0.001)\end{array}$ & $\begin{array}{c}0.0008^{* *} \\
(0.004)\end{array}$ & $\begin{array}{l}0.00065 \\
(0.0008)\end{array}$ \\
\hline $\begin{array}{l}\text { Total school } \\
\text { possession }\end{array}$ & $\begin{array}{l}0.0002^{* * *} \\
(4.1 \mathrm{e}-05)\end{array}$ & $\begin{array}{l}7.97^{* * *} \\
(1.647)\end{array}$ & $\begin{array}{l}3.843^{* *} \\
(1.643)\end{array}$ & $\begin{array}{c}0.0002^{* * *} \\
(4.46 \mathrm{e}-05)\end{array}$ & $\begin{array}{l}0.250^{* *} \\
(0.117)\end{array}$ & $\begin{array}{c}0.099^{* * *} \\
(0.09)\end{array}$ \\
\hline $\begin{array}{l}\text { Permanent } \\
\text { classes }\end{array}$ & $\begin{array}{c}0.285 \\
(2.741)\end{array}$ & $\begin{array}{l}-2.13 \\
(1.45)\end{array}$ & $\begin{array}{l}1.768^{\star} \\
(0.923)\end{array}$ & $\begin{array}{l}0.417 \\
(0.03)\end{array}$ & $\begin{array}{l}-0.201^{\star *} \\
(0.0944)\end{array}$ & $\begin{array}{c}0.019^{* * *} \\
(0.521)\end{array}$ \\
\hline $\begin{array}{l}\text { Temporary } \\
\text { classes }\end{array}$ & $\begin{array}{c}0.611 \\
(2.937)\end{array}$ & $\begin{array}{l}-2.874 \\
(1.891)\end{array}$ & $\begin{array}{c}1.216 \\
(1.539)\end{array}$ & $\begin{array}{c}0.77 \\
(3.215)\end{array}$ & $\begin{array}{c}-0.0492 \\
(0.1230\end{array}$ & $\begin{array}{c}-0.0137 \\
(0.678)\end{array}$ \\
\hline Open classes & $\begin{array}{l}-2.192 \\
(4.705)\end{array}$ & $\begin{array}{c}-5.652^{* *} \\
(2.551)\end{array}$ & $\begin{array}{c}1.817 \\
(3.131)\end{array}$ & $\begin{array}{l}-3.005 \\
(5.15)\end{array}$ & $\begin{array}{c}-0.289^{*} \\
(0.167)\end{array}$ & $\begin{array}{l}0.0395^{*} \\
(0.234)\end{array}$ \\
\hline $\begin{array}{l}\text { Distance from } \\
\text { clinic }\end{array}$ & $\begin{array}{l}-0.0146 \\
(0.0123)\end{array}$ & $\begin{array}{c}-0.0196^{* *} \\
(0.00969)\end{array}$ & $\begin{array}{l}-0.021^{\star \star} \\
(0.00824)\end{array}$ & $\begin{array}{c}-0.0152 \\
(0.013)\end{array}$ & $\begin{array}{l}-0.03^{* * *} \\
(0.0109)\end{array}$ & $\begin{array}{l}-0.02^{\star *} \\
(0.0104)\end{array}$ \\
\hline $\begin{array}{l}\text { Distance from } \\
\text { road }\end{array}$ & $\begin{array}{l}-0.022^{* * *} \\
(0.00755)\end{array}$ & $\begin{array}{l}-0.00789 \\
(0.00701)\end{array}$ & $\begin{array}{l}-0.00079 \\
(0.00897)\end{array}$ & $\begin{array}{c}-0.024^{\star * *} \\
(0.008)\end{array}$ & $\begin{array}{l}-0.019^{* *} \\
(0.0073)\end{array}$ & $\begin{array}{l}-0.0114 \\
(0.0101)\end{array}$ \\
\hline $\begin{array}{c}\text { Distance from } \\
\text { library }\end{array}$ & $\begin{array}{c}0.0125(0.009 \\
35)\end{array}$ & $\begin{array}{l}-0.00836 \\
(0.00623)\end{array}$ & $\begin{array}{l}-0.0118^{*} \\
(0.00666)\end{array}$ & $\begin{array}{c}0.013 \\
(0.00982)\end{array}$ & $\begin{array}{c}-0.0093 \\
(0.00702)\end{array}$ & $\begin{array}{l}-0.014^{*} \\
(0.0081)\end{array}$ \\
\hline $\begin{array}{c}\text { Distance } \\
\text { bookshop }\end{array}$ & $\begin{array}{c}-0.0223^{* *} \\
(0.00995)\end{array}$ & $\begin{array}{l}-0.00912 \\
(0.00785)\end{array}$ & $\begin{array}{l}-0.00629 \\
(0.00678)\end{array}$ & $\begin{array}{c}-0.0231^{* *} \\
(0.0104)\end{array}$ & $\begin{array}{l}-0.02^{\star * *} \\
(0.0082)\end{array}$ & $\begin{array}{c}-0.0095 \\
(0.008)\end{array}$ \\
\hline $\begin{array}{c}\text { Distance from } \\
\text { secondary } \\
\text { School }\end{array}$ & $\begin{array}{l}0.0260^{* * *} \\
(0.00986)\end{array}$ & $\begin{array}{c}0.0129 \\
(0.00798)\end{array}$ & $\begin{array}{l}-0.00314 \\
(0.00579)\end{array}$ & $\begin{array}{c}0.0276^{* * *} \\
(0.0104)\end{array}$ & $\begin{array}{l}0.025^{\star \star \star} \\
(0.0091)\end{array}$ & $\begin{array}{l}-0.0036 \\
(0.0075)\end{array}$ \\
\hline $\begin{array}{l}\text { Total school } \\
\text { possession }\end{array}$ & $\begin{array}{c}0.257 \\
(1.565)\end{array}$ & $\begin{array}{l}3.768^{* *} \\
(1.871)\end{array}$ & $\begin{array}{l}-0.284 \\
(1.856)\end{array}$ & $\begin{array}{l}-0.206 \\
(1.687)\end{array}$ & $\begin{array}{l}4.670^{* *} \\
(1.838)\end{array}$ & $\begin{array}{c}1.238 \\
(1.973)\end{array}$ \\
\hline
\end{tabular}

${ }^{* * *} \mathrm{p}<0.01,{ }^{* *} \mathrm{p}<0.05,{ }^{*} \mathrm{p}<0.1$; Standard errors in parentheses. Source: Authors computation based on SACMEQ survey data.

Carnoy, Ngware and Oketch (2015) who noted that schools resources and school characteristics majorly contributed to student learning as evidenced in 2000 before the introduction of FPE [61] [62].

The analysis on the relationship between class type and quality of education was addressed by Rowe (1988) who affirmed that regardless of class type, tem- 
porary and permanent classes were statistically significant with quality of education. In addition, school location relationship with quality of education was supported by Alokan [63] and Coniine and Zappala (2002) who noted that no school set of infrastructure can claim superior performance, though various studies reported the opposite (see also Yodeled, 1988 and Ocoee and yare, 2010).

The enrolment shock in 2004 marginally affected relationship between school possession and quality of education given the various school characteristics, a fact that agreed with Tow (2006) who found that effects of school funding affect student academic achievement though the assertion would be supported by other variables such as school and teacher characteristics [64] [65].

\subsection{Effect of Government Expenditure and Quality of Education Given Teacher Characteristics}

To establish the effect of government expenditure on the quality of education in relation to teacher characteristics, coefficients for government expenditure and quality of education controlled for teacher experience were negative and statistically significant for both arithmetic and reading scores in the three-time period respectively in Table 4.

The coefficients for government expenditure and quality of education controlled for teacher experience, pupil-teacher ratio and teacher number is given both arithmetic and reading scores in the three-time period respectively agreed with Viscusi and Gayer [66] and Tullock [67] who noted that teacher numbers could have had significant relationship with student achievement especially in arithmetic. The relationship was limited to the environment with which class-pupil and pupil-teacher ratios were managed.

Further, coefficients for teacher experience and quality of education were closely related given government expenditure and arithmetic and reading scores were related to Glewwe and Kremer [68] and Clotfelter et al. [69] who found that inexperienced teachers were less effective with little knowledge on the level of effectiveness undertaken in different types of preparation [70] [71].

\section{Conclusions and Policy Recommendations}

\subsection{Conclusions}

School performance is depended on various variables that are related to changes in government expenditure. The degree of relationship between various variables determining quality of education with variated government expenditure has been carried out from pupils' achievement and aggregated school achievement. These results had been subjected to a significance test at each level of correlation [72].

There exist high statistical significance and correlation levels between variables in the study and school performance especially in arithmetic and reading across the three-time periods. There was a positive relationship between book-pupil ratio, class-pupil ratio, school location within small town and large 
Table 4. Government expenditure and quality of education given teacher characteristics.

\begin{tabular}{|c|c|c|c|c|c|c|}
\hline \multicolumn{7}{|c|}{ Panel Regression Analysis } \\
\hline Variables & $\begin{array}{l}\text { Arithmetic } \\
\text { Score } 2000\end{array}$ & $\begin{array}{l}\text { Arithmetic } \\
\text { Score } 2004\end{array}$ & $\begin{array}{l}\text { Arithmetic } \\
\text { Score } 2012\end{array}$ & $\begin{array}{c}\text { reading } \\
\text { Score } 2000\end{array}$ & $\begin{array}{c}\text { reading } \\
\text { Score } 2004\end{array}$ & $\begin{array}{c}\text { reading } \\
\text { Score } 2012\end{array}$ \\
\hline \multicolumn{7}{|c|}{ Teacher Numbers and Pupil-Teacher Ratio } \\
\hline Total Teachers & $\begin{array}{c}-19.64^{* * *} \\
(3.573)\end{array}$ & $\begin{array}{l}1.734^{* * *} \\
(0.509)\end{array}$ & $\begin{array}{c}0.835 \\
(0.625)\end{array}$ & $\begin{array}{c}-22.6^{* * *} \\
(3.918)\end{array}$ & $\begin{array}{c}85.34^{* * *} \\
(15.36)\end{array}$ & $\begin{array}{c}1.297 \\
(1.067)\end{array}$ \\
\hline Pupil-teacher ratio & $\begin{array}{l}1.225^{\star *} \\
(0.513)\end{array}$ & $\begin{array}{c}-1.74^{* * *} \\
(0.181)\end{array}$ & $\begin{array}{c}-1.02^{* * *} \\
(0.269)\end{array}$ & $\begin{array}{l}1.12^{* *} \\
(0.545)\end{array}$ & $\begin{array}{c}-1.79 * * * \\
(0.449)\end{array}$ & $\begin{array}{c}-1.32^{* * *} \\
(0.312)\end{array}$ \\
\hline \multicolumn{7}{|c|}{ Teacher Experience } \\
\hline No experience & $\begin{array}{c}24.01^{\star * *} \\
(3.827)\end{array}$ & $\begin{array}{c}-5.84 \\
(51.95)\end{array}$ & $\begin{array}{c}0.324 \\
(0.761)\end{array}$ & $\begin{array}{l}27.3^{\star * *} \\
(4.197)\end{array}$ & $\begin{array}{c}-74.3^{\star * *} \\
15.44)\end{array}$ & $\begin{array}{l}1.375 \\
(1.15)\end{array}$ \\
\hline Less than 1 year & $\begin{array}{l}11.72^{* *} \\
(4.825)\end{array}$ & $\begin{array}{l}-5.206 \\
(52.63)\end{array}$ & $\begin{array}{c}1.23 \\
(0.888)\end{array}$ & $\begin{array}{l}16.3^{\star * *} \\
(5.291)\end{array}$ & $\begin{array}{c}-87.7^{\star * *} \\
(15.99)\end{array}$ & $\begin{array}{l}3.88^{* * *} \\
(1.302)\end{array}$ \\
\hline At least 1 year & $\begin{array}{c}21.46^{* * *} \\
(3.529)\end{array}$ & $\begin{array}{l}-6.98 \\
(53.3)\end{array}$ & $\begin{array}{c}-3.92^{* * *} \\
(1.304)\end{array}$ & $\begin{array}{c}11.5^{* * *} \\
(1.3)\end{array}$ & $\begin{array}{l}-98.0^{* * *} \\
(16.39)\end{array}$ & $\begin{array}{l}-2.88^{* * *} \\
(1.074)\end{array}$ \\
\hline At least 2 years & $\begin{array}{c}1.888^{* * *} \\
(0.155)\end{array}$ & $\begin{array}{c}-0.0174 \\
(51.59)\end{array}$ & $\begin{array}{c}4.329 \\
(0.662)\end{array}$ & $\begin{array}{l}22.8^{* * *} \\
(4.037)\end{array}$ & $\begin{array}{l}-81.2^{* * *} \\
(15.35)\end{array}$ & $\begin{array}{l}2.298^{* *} \\
(1.078)\end{array}$ \\
\hline At least 3 years & $\begin{array}{c}7.199^{\star * *} \\
(0.761)\end{array}$ & $\begin{array}{l}-5.184 \\
(51.63)\end{array}$ & $\begin{array}{c}1.738^{* * *} \\
(0.578)\end{array}$ & $\begin{array}{l}28.1^{\star * *} \\
(-4.163)\end{array}$ & $\begin{array}{c}-86.1^{\star * *} \\
(15.28)\end{array}$ & $\begin{array}{c}1.213 \\
(1.355)\end{array}$ \\
\hline More than 3 years & $\begin{array}{l}21.52^{\star * *} \\
(2.849)\end{array}$ & $\begin{array}{c}16.85 \\
(54.36)\end{array}$ & $\begin{array}{l}1.929^{\star} \\
(0.988)\end{array}$ & $\begin{array}{l}42.9^{\star * *} \\
(7.066)\end{array}$ & $\begin{array}{c}-82.1^{\star \star \star} \\
(17.85)\end{array}$ & $\begin{array}{c}3.941^{\star * *} \\
(1.31)\end{array}$ \\
\hline \multicolumn{7}{|c|}{ Teacher Qualification } \\
\hline $\begin{array}{c}\text { Teacher with } \\
\text { primary education }\end{array}$ & $\begin{array}{l}137.0^{* * *} \\
(51.48)\end{array}$ & $\begin{array}{c}34.13 \\
(55.67)\end{array}$ & $\begin{array}{c}-7.21^{* * *} \\
(2.5)\end{array}$ & $\begin{array}{l}156.6^{* * *} \\
(55.45)\end{array}$ & $\begin{array}{l}77.43 \\
(51.6)\end{array}$ & $\begin{array}{l}-6.6^{* *} \\
(3.02)\end{array}$ \\
\hline $\begin{array}{c}\text { Teacher with } \\
\text { secondary } \\
\text { education }\end{array}$ & $\begin{array}{c}137.4^{\star * *} \\
(51.46)\end{array}$ & $\begin{array}{c}39.19 \\
(55.46)\end{array}$ & $\begin{array}{c}0 \\
(0)\end{array}$ & $\begin{array}{c}157.4^{\star \star \star} \\
(55.43)\end{array}$ & $\begin{array}{l}81.56 \\
(51.4)\end{array}$ & $\begin{array}{c}-0.005 \\
(3.59)\end{array}$ \\
\hline $\begin{array}{c}\text { Teacher with } \\
\text { Tertiary education }\end{array}$ & $\begin{array}{l}135.7^{* * *} \\
(51.49)\end{array}$ & $\begin{array}{c}39.48 \\
(55.42)\end{array}$ & $\begin{array}{c}8.190^{* * *} \\
(3.011)\end{array}$ & $\begin{array}{l}155.7^{* * *} \\
(55.44)\end{array}$ & $\begin{array}{c}81.7 \\
(51.4)\end{array}$ & $\begin{array}{c}0 \\
(0)\end{array}$ \\
\hline $\begin{array}{c}\text { Teacher } \\
\text { Abseentism }\end{array}$ & $\begin{array}{l}-24.82 \\
(26.04)\end{array}$ & $\begin{array}{c}-19.51 \\
(19.3)\end{array}$ & $\begin{array}{c}20.32 \\
(16.67)\end{array}$ & $\begin{array}{l}-23.01 \\
(24.16)\end{array}$ & $\begin{array}{c}-26.28 \\
(17.9)\end{array}$ & $\begin{array}{l}13.29 \\
(14.9)\end{array}$ \\
\hline Teacher Laziness & $\begin{array}{l}-20.11 \\
(12.02)\end{array}$ & $\begin{array}{c}-4.82 \\
(10.33)\end{array}$ & $\begin{array}{c}6.978 \\
(14.79)\end{array}$ & $\begin{array}{c}-16.83 \\
(11.8)\end{array}$ & $\begin{array}{c}-4.996 \\
(9.59)\end{array}$ & $\begin{array}{c}10.1 \\
(13.6)\end{array}$ \\
\hline
\end{tabular}

${ }^{* * *} \mathrm{p}<0.01,{ }^{* *} \mathrm{p}<0.05,{ }^{*} \mathrm{p}<0.1$; Standard errors in parentheses. Source: authors computation based on SACMEQ survey data.

town and city, school possession and government expenditure. The relationship indicated that they were key factors for consideration in school performance levels. School distance from social amenities related to all other variables showed that they were negatively related to the quality of education. These findings were consistent with Greenwald, et al. [60] and Michaelowa and Wittmann [73] studies on effects of school resources on student achievement in Francophone sub-Saharan Africa.

Notably, teacher characteristics have a highly statistically significant relation- 
ship with quality of education at school level achievement, thus critical in school performance. Teacher experience is also crucial in determining school performance. These outcomes were also outlined in Greenwald et al. [60] and Lee, Zuve \& Ross [74] while investigating school effectiveness in 14 sub-Saharan African counties and realized that with increased class size, teacher's satisfaction is low which also affects the pupils' performance.

\subsection{Policy Recommendations}

The fact that government expenditure has been seen to influence quality also affects other necessary variables that may impact the quality of education. In a school setting, the government role in development of policies on education that targets to spur quality of education, school characteristics such as number of classes, number of teachers and number of toilets are outlined [12]-[21], adopted and implemented by the various stakeholders who have identified the causal relationship between available resources and quality of education given other variables controlled for [6] [22] [23] [60] [75] [76] [77].

Although the government has for a long time measured UPE policy from access levels expressed by school enrolment, it's clear that school performance defines more especially quality of education which can be affected by variables such as class-pupil ratio, pupil-teacher ratio, pupil-book ratio, and pupil-toilet ratios. Studies by Klees [31], Bold, et al. [22]; Mazar et al. [23] and Cohen \& Dupas [24] noted that the existing ratios in Kenya were above the internationally recognized standards which will affect performance negatively. In regard to these, the government should develop guidelines on the nationally stipulated class-pupil ratio, pupil-teacher ratio, pupil-book ratio and pupil-toilet ratios that are adaptable in all schools as the new curriculum 2-6-3-3-3 are implemented as it will ensure the ratio that leads to enhanced school performance achieved.

\section{Conflicts of Interest}

The authors declare no conflicts of interest regarding the publication of this paper.

\section{References}

[1] Mincer, J. (1974) Schooling, Experience, and Earnings. National Bureau of Economic Research, Columbia University Press, New York.

[2] Persson, T. and Tabellini, G. (1994) Is Inequality Harmful to Growth? American Economic Review, 84, 600-621.

[3] Alesina, A. and Dani Rodrik, D. (1994) Distributive Politics and Economic Growth. Quarterly Journal of Economics, 108, 465-490. https://doi.org/10.2307/2118470

[4] Okeke, B.C. (2014) Impact of Public Sector Spending on Health and Education Outcomes in Nigeria. Department of Economics, University of Nigeria, Nsukka.

[5] World Bank (2010) Kenya, Free Primary Education Support Project. Project ID: P082378.

[6] Krueger, A. and Lindahl, M. (2001) Education for Growth: Why and for Whom? 
Journal of Economic Literature, 39, 1101-1136. https://doi.org/10.1257/jel.39.4.1101

[7] Sianesi, B. and Van Reenen, R. (2003) The Returns to Education, Macroeconomics. Journal of Economic Surveys, 17, 157-200. https://doi.org/10.1111/1467-6419.00192

[8] Odo, S.I., Nwachukwu, J.O. and Agbi, P.E. (2016) Public Expenditure on Social Capital: Implications for Economic Growth in Nigeria. Journal of Economics and Sustainable Development, 7, 72-79.

[9] Republic of Kenya (2008) The Development of Education, National Report of Kenya. International Conference on Education, Geneva, 25-28 November 2008.

[10] Republic of Kenya (2012) Taskforce on the Re-Alignment of the Education Sector to the Constitution of Kenya 2010: Towards Globally Competitive Quality Education for Sustainable Development. Report of the Task Force, Nairobi.

[11] Vos, R., Bedi, A., Kimalu, P., Manda, D., Nafula, N. and Kimenyi, M. (2004) Achieving Universal Primary Education: Can Kenya Afford It? Economics Working Papers. Paper No. 200447. http://digitalcommons.uconn.edu/econ_wpapers/200447

[12] Republic of Kenya (GOK) (1964) Kenya Education Commission. Government Printer, Nairobi.

[13] Republic of Kenya (GOK) (1981) Second University in Kenya (Mackay Report). Government Printer, Nairobi.

[14] Republic of Kenya (GOK) (1988) Report of the Presidential Working Party on Education and Manpower Training for the Next Decade and Beyond. Kamunge Report, Government Printer, Nairobi.

[15] Republic of Kenya (GOK) (2000) Report of the Inquiry into the Education System of Kenya (TI QET). Koech Report, Government Printer, Nairobi.

[16] Republic of Kenya (GOK) (2005) Sessional Paper No.1 on Policy Framework for Education, Training and Research. Government Printer, Nairobi.

[17] Republic of Kenya (2005) KESSP Report on Delivery Quality Education and Training to All Kenyans. Government Printer Sustainable Development.

[18] Republic of Kenya (2005) Sessional Paper No. 1 of 2005. A Policy Framework for Education, Training, and Research, MOEST.

[19] Republic of Kenya (2005) Kenya Educational Sector Support Programme (KESSP) 2005-2010. Government Printer.

[20] Republic of Kenya (2007) Economic Surveys (1998-2007).

[21] Republic of Kenya (2009) Actualizing Free Primary Education in Kenya for Sustainable Development. The Journal of Pan African Studies, 2.

[22] Bold, T., Kimenyi, M., Mwabu, G. and Sandefur, J. (2011) Why Did Abolishing Fees Not Increase Public School Enrolment in Kenya, Centre for Global Development? Working Paper No. 271. https://doi.org/10.2139/ssrn.1972336

[23] Mazar, N., Ariely, A. and Shampanier, R. (2007) Zero as a Special Price. The True Value of Free Products. Marketing Science, 26, 742-757. https://doi.org/10.1287/mksc.1060.0254

[24] Cohen, J. and Dupas, P. (2010) Free Distribution or Cost-Sharing? Evidence from Randomized Malaria Prevention Experiment. Quarterly Journal of Economics, 125, 1-25. https://doi.org/10.1162/qjec.2010.125.1.1

[25] World Bank Group (2016) Pakistan: Tracing the Flow of Public Money: Expenditure and Quantity of Service Delivery Survey (EQSDS) in Primary School, WB, BOP, and DFID.

[26] Bedi, A., Kimalu, P., Kulundu, D. and Nafula, N. (2002) The Decline in Primary 
School Enrolment in Kenya. KIPPRA Discussion Paper No. 14, KIPPRA, Nairobi.

[27] Kimalu, P.K., Nafula, N., Kulundu, D.K., Bedi, A., Mwabu, G. and Kaimenyi, S.M. (2001) Education Indicators in Kenya. KIPPRA Working Paper, KIPPRA, Nairobi.

[28] Nero, S. (2003) Reflective Collaboration between NES and NNES in an MA-TESOL Program. Colloquium Panellist at TESOL Convention, Baltimore, MD.

[29] Mukundi, E. (2004) Education for All: A Framework for Addressing the Persisting Illusion for the Kenyan Context. International Journal of Educational Development, 24, 231-240. https://doi.org/10.1016/j.ijedudev.2003.10.009

[30] Muyanga, M., Olwande, J., Mueni, E. and Wambugu, S. (2010) Free Primary Education in Kenya: An Impact Evaluation Using Propensity Score Methods. PMMA Working Paper 2010-08. https://doi.org/10.1007/978-1-4419-6275-1_5

[31] Klees, S. (2008) A Quarter Century of Neoliberal Thinking in Education: Misleading Analysis and Failed Policies. Globalization, Societies and Education, 6, 311-348. https://doi.org/10.1080/14767720802506672

[32] Musyoka, P. (2013) Nationally Standardised Continuous Assessment Tests at Various Grades for Improved Academic Achievement. APHRC, Briefing Paper

[33] UNESCO (2010) EFA Global Monitoring Report.

[34] Smith, A. (2000) The Wealth of Nations. Modern Library, New York, 1723-1790.

[35] Marshall, A. (1890) Principles of Economics. Macmillan, London.

[36] Earle, D. (2010) Labour Market Outcomes of Skills and Qualifications, Tertiary Education. Occasional Paper 2010/5, New Zealand Ministry of Education, New Zealand.

[37] Ali, M., Egbetokun, A. and Memon, M. (2018) Human Capital, Social Capabilities and Economic Growth. Economics, 6, 2. https://doi.org/10.3390/economies6010002

[38] Zhu, S.J. and Li, R.Y. (2017) Economic Complexity, Human Capital, and Economic Growth: Empirical Research Based on Cross-Country Panel Data. Applied Economics, 49, 3815-3828. https://doi.org/10.1080/00036846.2016.1270413

[39] Uwe, S. and Vischer, T. (2015) Human Capital and Growth: Specification Matters. Economica, 82, 368-390. https://doi.org/10.1111/ecca.12116

[40] Ferrer, A.M. and Riddell, W.C. (2002) The Role of Credentials in the Canadian Labor Market. Canadian Journal of Economics, 35, 879-905. https://doi.org/10.1111/0008-4085.00158

[41] Schultz, T.W. (1961) Investment in Human Capital. American Economic Review, 51, 1-17.

[42] Ashenfelter, O. and Krueger, A. (1994) Estimating the Returns to Schooling Using a New Sample of Twins. American Economic Review, 84, 1157-1173.

[43] Block, F. (1990) Post-industrial Possibilities: A Critique of Economic Discourse. California University Press, Berkeley, CA.

[44] Marginson, S. (1993) Education and Public Policy in Australia. Cambridge University Press, Melbourne, Australia.

[45] Becker, G. (1994) Human Capital: A Theoretical and Empirical Analysis with Special Reference to Education. 3rd Edition, The University of Chicago Press, Chicago, IL. http://www.nber.org/books/beck94-1

[46] Becker, G. and Nigel, T. (1979) An Equilibrium Theory of the Distribution of Income and Intergenerational Mobility. Journal of Political Economy, 87, 1153-1189. https://doi.org/10.1086/260831

[47] Becker, G. and Nigel, T. (1986) Human Capital and the Rise and Fall of Families. 
Journal of Labor Economics, 4, S1-S39. https://doi.org/10.1086/298118

[48] Mizala, A. and Rumaguera, P. (2000) School Performance and Choice: The Children Experience. Journal of Human Resources, 35, 392-417. https://doi.org/10.2307/146331

[49] Cameron, S. and Heckman, J. (2001) The Dynamics of Educational Attainment for Black, Hispanic and White Males. Journal of Political Economy, 109, 455-499.

[50] Abt Associates (2007) Evaluation of the Expanded Learning Time Initiative. Year 1 Report 2006-2007. Massachusetts Department of Education, Malden, MA.

[51] Hanushek, E.A. (1986) The Economic of Schooling Production and Efficiency in Public Schools. Journal of Economic Literacy, 24, 1141-1177.

[52] Machin, S. and Vignoles, A. (2005) Education Policy and the Evidence. In: Machin, S. and Vignoles, A., Eds., What's the Good of Education? The Economics of Education in the UK, Princeton University Press, Oxford. https://doi.org/10.1515/9780691188652-014

[53] Ruggiero, J. (2004) Performance Evaluation in Education. In: Cooper, W.W., Seiford, L. and Zhu, J., Eds., Handbook on Data Envelopment Analysis, Kluwer, Netherlands.

[54] Taylor, B.M., Pearson, P.D., Clark, K. and Walpole, S. (2000) Effective Schools and Accomplished Teachers: Lessons about Primary-Grade Reading Instruction in Low-Income Schools. The Elementary School Journal, 101, 121-165. https://doi.org/10.1086/499662

[55] King, K., McGrathc, S. and Rosed, P. (2007) Beyond the Basics: Educating and Training out of Poverty. International Journal of Educational Development, 27, 349-357. https://doi.org/10.1016/j.ijedudev.2007.03.001

[56] Hamish, C. and Rothman, S. (1998) Participation in VET in Schools. LSAY Briefing Reports. https://research.acer.edu.au/lsay_briefs/14

[57] Ferguson, R.F. and Ladd, H.F. (1996) How and Why Money Matters: An Analysis of Alabama Schools. In: Ladd, H.F., Ed., Holding Schools Accountable. Performance-Based Reform in Education, Brooking Institution, Washington DC, 265-298.

[58] Ladd, H.F., Roselins, B.L. and Walsh, R.P. (1997) Using Student Test Scores to Measure Effective Schools. The Annual Conference of the Association for Public Policy Analysis and Management, Washington DC.

[59] Terza, J., Basu, A. and Rathouz, P. (2008) Two-Stage Inclusion Estimation: Addressing Endogeneity in Health Econometric Modelling. Journal of Health Economics, 27, 531-543. https://doi.org/10.1016/j.jhealeco.2007.09.009

[60] Greenwald, R., Hedges, V. and Laine, R. (1996) The Effect of School Resources on Student Achievement. Review of Educational Research, 66, 361-396. https://doi.org/10.3102/00346543066003361

[61] Fedderke, J.W. and Luiz, J.M. (2002) Production of Educational Output: Time Series Evidence from Socioeconomically Heterogeneous Populations-The Case of South Africa, 1927-1993. Economic Development and Cultural Change, 51, 161-188. https://doi.org/10.1086/345575

[62] Carnoy, M., Loeb, S. and Smith, T. (2001) Do Higher State Test Scores in Texas Make for Better High School Outcomes? CPRE Research Report No. RR-047, Consortium for Policy Research in Education, Philadelphia, PA. https://doi.org/10.1037/e383872004-001

[63] Alokan, F.B. (2010) Influence of Sex and Location on Relationship between Student Problems and Academic Performance. The Social Sciences, 5, 340-345. 
https://doi.org/10.3923/sscience.2010.340.345

[64] Lips, D., Watkins, S.L. and Fleming, J. (2008) Does Spending More on Education Improve Academic Achievement? Backgrounder Report No. 2179, The Heritage Foundation, Washington DC.

[65] Wobmann, L. and West, M. (2006) Class-Size Effects in School Systems around the World: Evidence from between-Grade Variation in TIMSS. European Economic Review, 50, 695-736. https://doi.org/10.1016/j.euroecorev.2004.11.005

[66] Viscusi, W. and Gayer, T. (2015) Behavioral Public Choice: The Behavioral Paradox of Government Policy. Vanderbilt Law and Economics Research Paper No. 15-2. https://doi.org/10.2139/ssrn.2559408

[67] Tullock, G. (2006) Public Goods, Redistribution and Rent-Seeking. Economica, 73, 563-794. https://doi.org/10.1111/j.1468-0335.2006.00039_2.x

[68] Glewwe, P. and Kremer, M. (2006) Schools, Teachers and Education Outcomes in Developing Countries. In: Hanushek, E. and Welch, F., Eds., Handbook of the Economics of Education, Elsevier, North-Holland, 945-1017. https://doi.org/10.1016/S1574-0692(06)02016-2

[69] Clotfelter, J., Ladd, H. and Vigdor, J. (2011) Teacher Credentials and Student Achievement in High School: A Cross-Subject Analysis with Student Fixed Effects. Journal of Human Resources, 45, 655-681. https://doi.org/10.1353/jhr.2010.0023

[70] Njeru, E. and Orodho, J. (2003) Education Financing in Kenya: Secondary School-Bursary Scheme Implementation and Challenges. Institute of Policy Analysis and Research Discussion Paper (IPAR DP/035/2003), Nairobi.

[71] Sifuna, D. (2003) The Illusion of Universal Free Primary Education in Kenya. Wajibu, 19, 5-8.

[72] Bradley, G. (2006) Work Participation and Academic Performance: A Test of Alternative Propositions. Journal of Education and Work, 19, 481-501. https://doi.org/10.1080/13639080600988756

[73] Michaelowa, K. and Wittmann, E. (2007) The Cost, Satisfaction, and Achievement of Primary Education: Evidence from Francophone Sub-Saharan Africa. World Development, 29, 1699-1716. https://doi.org/10.1016/S0305-750X(01)00061-4

[74] Lee, V., Zuze, T. and Ross, K. (2005) School Effectiveness in 14 Sub-Saharan African Countries Links with 6th Grades Reading Achievement. Studies in Educational Evaluation, 31, 207-246. https://doi.org/10.1016/j.stueduc.2005.05.011

[75] David, C. and Krueger, A.B. (1996) School Resources and Student Outcomes: An Overview of the Literature and New Evidence from North and South Carolina. Journal of Economic Perspectives, 10, 31-50. https://doi.org/10.1257/jep.10.4.31

[76] Topel, R. (1999) Labor Market and Economic Growth: In: Ashenfelter, O. and Card, D., Eds., The Handbook of Labor Economics, Chapter 44, Elsevier, Amsterdam, North-Holland, 2943-2984. https://doi.org/10.1016/S1573-4463(99)30035-3

[77] Hanushek, E. and Woessmann, L. (2008) The Role of Cognitive Skills in Economic Development. Journal of Economic Literature, 46, 607-668.

https://doi.org/10.1257/jel.46.3.607 


\section{Appendices}

Table A1. Variables for Government expenditure and enrolment.

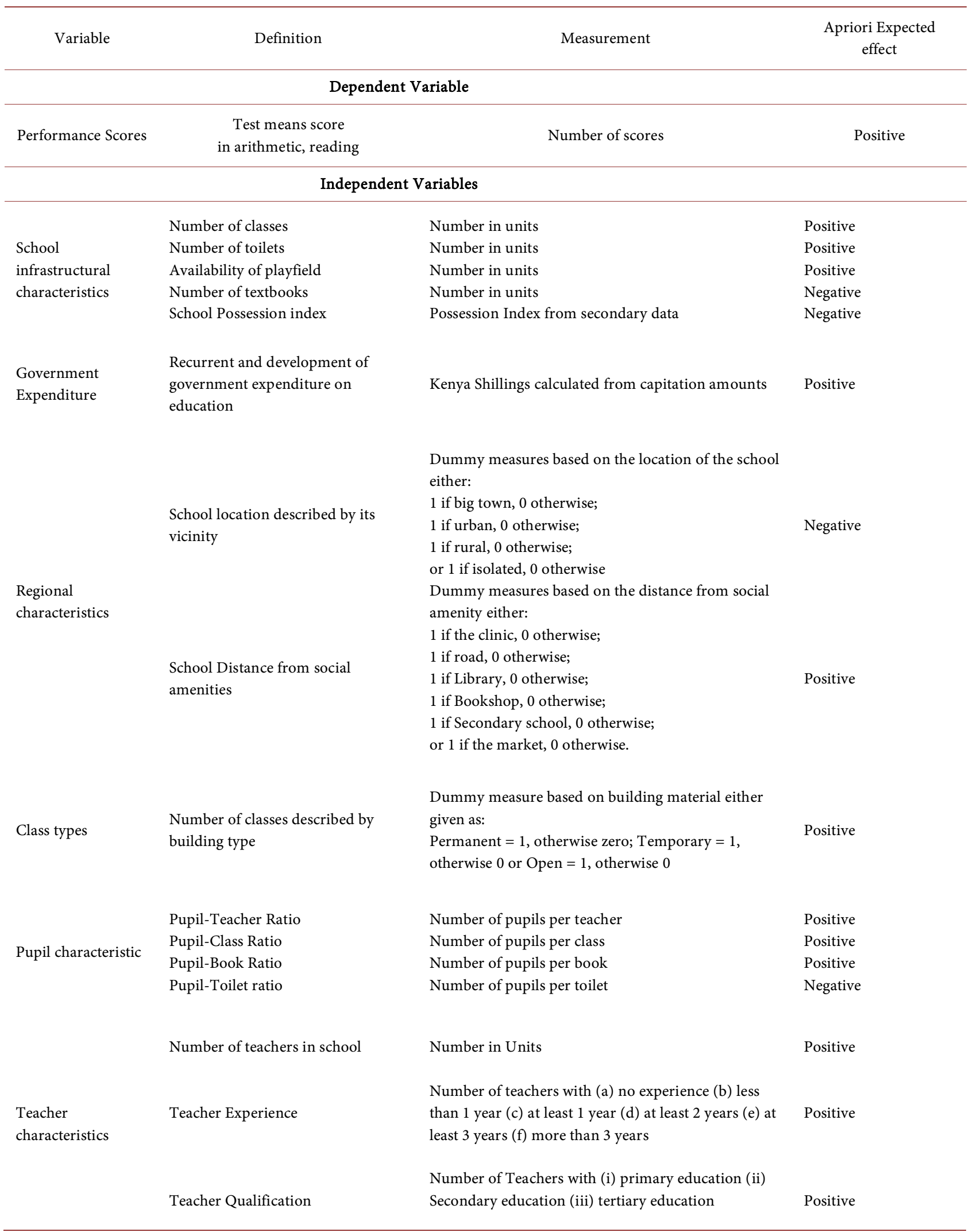


S. Mutuku, J. Korir

Table A2. Number and percentage of schools sampled.

\begin{tabular}{|c|c|c|c|c|c|}
\hline Year & 2000 & 2004 & 2012 & Mean & Standard Deviation \\
\hline Coast & $22(12.6 \%)$ & $18(10.4 \%)$ & $15(8.3 \%)$ & 18.3 & 3.51 \\
\hline Central & $35(20.1 \%)$ & $24(13.9 \%)$ & $23(12.7 \%)$ & 27 & 6 \\
\hline Eastern & $24(13.8 \%)$ & $23(13.3 \%)$ & $22(12.2 \%)$ & 23 & 1 \\
\hline Nairobi & $19(10.9 \%)$ & $19(10.98 \%)$ & $15(8.3 \%)$ & 17.7 & 2.3 \\
\hline Rift Valley & $24(13.8 \%)$ & $28(16.2 \%)$ & $38(20.99 \%)$ & 30 & 7.2 \\
\hline Nyanza & $20(11.5 \%)$ & $23(13.3 \%)$ & $34(18.8 \%)$ & 25 & 7.4 \\
\hline Western & $15(8.62 \%)$ & $24(13.9 \%)$ & $22(12.2 \%)$ & 20 & 4.72 \\
\hline North Eastern & $15(8.6 \%)$ & $14(8.1 \%)$ & $12(6.6 \%)$ & 13.7 & 1.53 \\
\hline Total & 174 & 173 & 181 & 176 & 4.35 \\
\hline
\end{tabular}

Table A3. Mean government expenditure.

\begin{tabular}{|c|c|c|c|c|c|c|}
\hline Province & Mean & $\begin{array}{l}\text { Standard } \\
\text { Deviation }\end{array}$ & Mean & $\begin{array}{l}\text { Standard } \\
\text { Deviation }\end{array}$ & Mean & $\begin{array}{l}\text { Standard } \\
\text { Deviation }\end{array}$ \\
\hline & \multicolumn{2}{|c|}{2000} & \multicolumn{2}{|c|}{2004} & \multicolumn{2}{|c|}{2012} \\
\hline Central & $1,030,890$ & $660,276.2$ & $769,811.8$ & $296,505.6$ & $480,274.6$ & $220,284.8$ \\
\hline Coast & $939,129.5$ & $752,259.7$ & $737,702.0$ & $356,629.7$ & $703,215.3$ & $361,027.2$ \\
\hline Eastern & $569,264.0$ & $287,237.9$ & $530,759.0$ & $256,185.5$ & $413,787.2$ & $217,930.1$ \\
\hline Nairobi & $1,205,449$ & $364,168.5$ & $1,216,258.0$ & $398,010.6$ & $1,282,608$ & $552,954.5$ \\
\hline North Eastern & $826,018.7$ & $478,641.5$ & $1,058,135.0$ & $643,337.2$ & $171,800.5$ & $32,021.6$ \\
\hline Nyanza & $543,366.1$ & $339,848.0$ & $518,805.4$ & $405,103.6$ & $484,393.8$ & $254,402.5$ \\
\hline Rift valley & $663,115.8$ & $264,743.3$ & $650,955.2$ & $273,526.7$ & $610,123.5$ & $337,802.0$ \\
\hline Western & $867,895.6$ & $556,341.1$ & $7,080,391.0$ & $342,887.2$ & $723,979.5$ & $357,703.4$ \\
\hline Total Mean & $5,614,238$ & & $12,562,818$ & & $4,870,182$ & \\
\hline
\end{tabular}

Source: Authors computation based on SACMEQ survey data.

Table A4. Mean scores in arithmetic and reading.

\begin{tabular}{|c|c|c|c|c|c|c|c|}
\hline \multicolumn{2}{|c|}{ Year } & \multicolumn{2}{|c|}{2000} & \multicolumn{2}{|c|}{2004} & \multicolumn{2}{|r|}{2012} \\
\hline Province & Variable & Mean & Std. deviation & Mean & Std. deviation & Mean & Standard Deviation \\
\hline \multirow{2}{*}{ Central } & Arithmetic & 557.1 & 69.95 & 552.39 & 55.34 & 576.43 & 61.82 \\
\hline & Reading & 561.36 & 74.88 & 551.53 & 57.87 & 575.46 & 74.69 \\
\hline \multirow{2}{*}{ Coast } & Arithmetic & 378.59 & 87.06 & 562.48 & 64.15 & 575.46 & 74.69 \\
\hline & Reading & 557.7 & 93.73 & 562.47 & 65.98 & 563.53 & 55.18 \\
\hline \multirow{2}{*}{ Eastern } & Arithmetic & 539.61 & 80.14 & 567.22 & 60.89 & 560.35 & 43.53 \\
\hline & Reading & 545.7 & 87.34 & 568.92 & 63.08 & 543.87 & 48.68 \\
\hline \multirow{2}{*}{ Nairobi } & Arithmetic & 628.64 & 105.49 & 622.35 & 55.35 & 606.59 & 85.83 \\
\hline & Reading & 636.87 & 113.86 & 628.75 & 59.89 & 624.76 & 74.57 \\
\hline \multirow{2}{*}{ North Eastern } & Arithmetic & 523.84 & 80.88 & 524.2 & 46.02 & 599.11 & 92.99 \\
\hline & Reading & 523.98 & 92.49 & 524.14 & 46.61 & 558.15 & 84.67 \\
\hline \multirow{2}{*}{ Nyanza } & Arithmetic & 507.05 & 71.28 & 530.93 & 52.68 & 555.18 & 37.89 \\
\hline & Reading & 508.85 & 80.39 & 531.32 & 54.58 & 542.13 & 51.92 \\
\hline \multirow{2}{*}{ Rift valley } & Arithmetic & 562.32 & 81.87 & 528.85 & 70.69 & 551.74 & 45.34 \\
\hline & Reading & 568.99 & 90.89 & 528.89 & 74.69 & 532.84 & 62.92 \\
\hline \multirow{2}{*}{ Western } & Arithmetic & 523.4 & 73.32 & 525.99 & 46.34 & 514.04 & 43.22 \\
\hline & Reading & 525.81 & 81.13 & 525.97 & 47.83 & 494.72 & 55.61 \\
\hline
\end{tabular}

Source: Authors computation based on SACMEQ survey data. 
Table A5. School location in 2000, 2004 and 2012.

\begin{tabular}{cccc}
\hline \multirow{2}{*}{ School location } & \multicolumn{3}{c}{ Number of schools and Percentage } \\
\cline { 2 - 4 } & $\mathbf{2 0 0 0}$ & $\mathbf{2 0 0 4}$ & $\mathbf{2 0 1 2}$ \\
\hline Isolated & $8(4.6 \%)$ & $4(2.31 \%)$ & $3(1.66 \%)$ \\
Rural & $90(51.72 \%)$ & $93(53.76 \%)$ & $115(63.54 \%)$ \\
Small town & $41(23.55 \%)$ & $33(19.08 \%)$ & $35(19.34 \%)$ \\
Large city/Urban & $35(20.1 \%)$ & $42(24.28 \%)$ & $28(15.47 \%)$ \\
Total & $\mathbf{1 7 4}$ & 172 & 181 \\
\hline
\end{tabular}

Source: Authors computation based on SACMEQ survey data.

Table A6. School distances from social amenities, Figures are mean (s.d).

\begin{tabular}{|c|c|c|c|c|c|c|c|c|c|}
\hline \multirow[b]{2}{*}{ Variables } & \multicolumn{3}{|c|}{2000} & \multicolumn{3}{|c|}{2004} & \multicolumn{3}{|c|}{2012} \\
\hline & Mean & Std Dev. & $\begin{array}{c}\text { No. of } \\
\text { Obs }\end{array}$ & Mean & Std Dev. & $\begin{array}{l}\text { No. of } \\
\text { Obs. }\end{array}$ & Mean & Std Dev. & No. of Obs \\
\hline \multicolumn{10}{|c|}{ Distance from: } \\
\hline clinic & 3.74 & 3.84 & 174 & 3.58 & 3.40 & 173 & 3.73 & 5.06 & 181 \\
\hline Road & 13.47 & 35.66 & 174 & 16.30 & 69.69 & 173 & 12.86 & 38.71 & 181 \\
\hline Library & 37.53 & 45.59 & 174 & 41.14 & 69.37 & 173 & 39.03 & 44.27 & 181 \\
\hline Bookshop & 16.56 & 33.46 & 174 & 11.58 & 23.15 & 173 & 16.27 & 31.68 & 181 \\
\hline Secondary school & 6.53 & 14.61 & 174 & 6.17 & 10.32 & 173 & 8.60 & 32.50 & 181 \\
\hline
\end{tabular}

Source: Authors computation based on SACMEQ survey data.

Table A7. School characteristics in 2000, 2004 and 2012.

\begin{tabular}{|c|c|c|c|c|c|c|}
\hline Variable & Year & No. of observation & Mean & Standard deviation & Min & $\operatorname{Max}$ \\
\hline \multirow{3}{*}{ Total Enrolment } & 2000 & 174 & 572.07 & 278.6 & 87 & 1355 \\
\hline & 2004 & 173 & 584.86 & 327.27 & 0 & 1729 \\
\hline & 2012 & 181 & 900.5 & 1534.4 & 88 & 12582 \\
\hline \multirow[b]{2}{*}{ Pupil class ratio } & 2000 & 174 & 36.4 & 10.4 & 9.32 & 67.25 \\
\hline & 2004 & 173 & 39.11 & 23.68 & 15.67 & 320.67 \\
\hline \multirow{3}{*}{ Pupil toilet ratio } & 2000 & 174 & 51.7 & 34.02 & 12 & 273 \\
\hline & 2004 & 173 & 53.11 & 70.99 & 5.93 & 750 \\
\hline & 2012 & 181 & 62.67 & 98.48 & 8 & 967.8 \\
\hline \multirow{3}{*}{ Pupil book ratio } & 2000 & 174 & 0.36 & 0.72 & 0 & 6.06 \\
\hline & 2004 & 173 & 0.66 & 1.55 & 0 & 10.52 \\
\hline & 2012 & 181 & 0.77 & 2.26 & 0 & 18.98 \\
\hline \multirow{3}{*}{ Teacher pupil ratio } & 2000 & 174 & 32.78 & 9.67 & 10.9 & 72.7 \\
\hline & 2004 & 173 & 34.22 & 9.38 & 13.1 & 67.43 \\
\hline & 2012 & 181 & 43.75 & 15.46 & 6.28 & 104.4 \\
\hline \multirow{3}{*}{ Government expenditure } & 2000 & 174 & $811,321.3$ & $1,224,179$ & 0 & $4,370,000$ \\
\hline & 2004 & 173 & $753,293.4$ & $421,517.5$ & 0 & $2,226,962$ \\
\hline & 2012 & 181 & $838,384.4$ & $1,428,610$ & 81,928 & $1,170,000$ \\
\hline \multirow{3}{*}{ Payment for tuition } & 2000 & 174 & 2.26 & 0.8 & 1 & 4 \\
\hline & 2004 & 173 & 1.63 & 0.48 & 1 & 2 \\
\hline & 2012 & 181 & 1.92 & 0.76 & 1 & 4 \\
\hline \multirow{3}{*}{$\begin{array}{l}\text { School Po } \\
\text { session }\end{array}$} & 2000 & 174 & 7.43 & 2.09 & 1 & 20 \\
\hline & 2004 & 173 & 7.99 & 3.48 & 1 & 20 \\
\hline & 2012 & 181 & 7.54 & 3.09 & 1 & 21 \\
\hline
\end{tabular}

Source: Authors computation based on SACMEQ survey data. 
Table A8. Number of schools with different class types.

\begin{tabular}{|c|c|c|c|c|c|c|c|c|c|}
\hline \multicolumn{10}{|c|}{ Number of schools and Percentage } \\
\hline \multirow[b]{2}{*}{ classes } & \multicolumn{3}{|c|}{2000} & \multicolumn{3}{|c|}{2004} & \multicolumn{3}{|c|}{2012} \\
\hline & Perm. & Temp. & Open & Perm. & Temp. & Open & Perm. & Temp. & Open \\
\hline \multirow{2}{*}{0} & 10 & 108 & 158 & \multirow{2}{*}{$2.31 \%$} & 115 & 158 & 9 & 111 & 168 \\
\hline & $5.55 \%$ & $62.1 \%$ & $90.8 \%$ & & $66.4 \%$ & $91.3 \%$ & $4.9 \%$ & $61.3 \%$ & $92.8 \%$ \\
\hline \multirow{2}{*}{$1-10^{\prime}$} & 71 & 61 & 16 & 60 & 54 & 14 & 69 & 64 & 13 \\
\hline & $39.4 \%$ & $35.1 \%$ & $9.19 \%$ & $34.7 \%$ & $31.2 \%$ & $8.09 \%$ & $38.1 \%$ & $35.3 \%$ & $7.18 \%$ \\
\hline \multirow{2}{*}{$11-20^{\prime}$} & 64 & 4 & 0 & 77 & 4 & 1 & 76 & 6 & 0 \\
\hline & $35.6 \%$ & $2.29 \%$ & (0\%) & $44.5 \%$ & $2.31 \%$ & $0.5 \%$ & $41.9 \%$ & $3.31 \%$ & $0 \%$ \\
\hline \multirow{2}{*}{$21-30^{\prime}$} & 22 & \multirow{2}{*}{$0.57 \%$} & 0 & 26 & 0 & 0 & 19 & 0 & 0 \\
\hline & $12.2 \%$ & & $0 \%$ & $15.02 \%$ & $0 \%$ & $0 \%$ & $10.5 \%$ & $0 \%$ & $(0 \%)$ \\
\hline \multirow{2}{*}{ 0ver 30} & 7 & 0 & 0 & 6 & 0 & 0 & 8 & 0 & 0 \\
\hline & $3.89 \%$ & (0\%) & $(0 \%)$ & $3.5 \%$ & (0\%) & $(0 \%)$ & $4.4 \%$ & $(0 \%)$ & (0\%) \\
\hline
\end{tabular}

${ }^{*}$ Perm $=$ permanent,${ }^{*}$ Temp $=$ Temporary,${ }^{* *}$ Open $=$ Open classes. Source: Authors computation based on SACMEQ survey data.

Table A9. Number of teachers disaggregated by gender (Figures are mean (s.d).

\begin{tabular}{cccccccccccc}
\hline & \multicolumn{2}{c}{2000} & & & 2004 & & \\
Variable & Mean & $\begin{array}{c}\text { Standard } \\
\text { Devia tion }\end{array}$ & $\begin{array}{c}\text { No. of } \\
\text { Observations }\end{array}$ & Mean & $\begin{array}{c}\text { Standard } \\
\text { Deviation }\end{array}$ & $\begin{array}{c}\text { No. of } \\
\text { Observations }\end{array}$ & $\begin{array}{c}\text { Mean } \\
\text { Standard } \\
\text { Deviation }\end{array}$ \\
Observations
\end{tabular}

Source: Authors computation based on SACMEQ survey data.

Table A10. Test for random and fixed effect.

\begin{tabular}{|c|c|c|c|c|}
\hline & (b) & (B) & $(b-B)$ & $\operatorname{sqrt}\left(\operatorname{diag}\left(\mathrm{V}_{-} \mathrm{b}-\mathrm{V}_{-} \mathrm{B}\right)\right)$ \\
\hline & Random & Fixed & Difference & S.E. \\
\hline Government Expenditure & $1.52 \mathrm{E}-28$ & $1.02 \mathrm{E}-29$ & $1.41 \mathrm{E}-28$ & $2.14 \mathrm{E}-17$ \\
\hline Total classes & $2.33 \mathrm{E}-24$ & $2.07 \mathrm{E}-24$ & $2.60 \mathrm{E}-25$ & $3.98 \mathrm{E}-12$ \\
\hline Number of Toilets & $-3.67 e-24$ & $-3.2 \mathrm{e}-26$ & $-3.6 e-24$ & $3.41 \mathrm{E}-13$ \\
\hline Total school possession & $1.06 \mathrm{E}-23$ & $2.59 \mathrm{E}-25$ & $1.03 \mathrm{E}-23$ & $1.09 \mathrm{E}-12$ \\
\hline Availability of playfield & $-2.35 \mathrm{e}-24$ & $-1.92 \mathrm{e}-24$ & $-4.23 e-25$ & $5.93 \mathrm{E}-12$ \\
\hline school distance from clinic & $1.17 \mathrm{E}-24$ & $7.24 \mathrm{E}-26$ & $1.10 \mathrm{E}-24$ & $6.16 \mathrm{E}-13$ \\
\hline School distance from road & $-1.08 \mathrm{e}-25$ & $-4.29 \mathrm{e}-27$ & $-1.04 \mathrm{e}-25$ & $7.07 \mathrm{E}-14$ \\
\hline School distance from library & $-1.6 \mathrm{e}-25$ & $4.37 \mathrm{E}-28$ & $-1.61 \mathrm{e}-25$ & $6.47 \mathrm{E}-14$ \\
\hline School distance from bookshop & $2.63 \mathrm{E}-25$ & $3.81 \mathrm{E}-26$ & $2.25 \mathrm{E}-25$ & $4.10 \mathrm{E}-12$ \\
\hline Temporary classes & $-5.41 \mathrm{e}-24$ & $-2.34 \mathrm{e}-24$ & $-3.06 \mathrm{e}-24$ & $4.19 \mathrm{E}-12$ \\
\hline Open classes & $-4.66 \mathrm{e}-24$ & $-2.1 \mathrm{e}-24$ & $-2.56 \mathrm{e}-24$ & $4.49 \mathrm{E}-12$ \\
\hline \multicolumn{5}{|l|}{ School Location } \\
\hline Isolated & $8.31 \mathrm{E}-22$ & $7.42 \mathrm{E}-25$ & $8.30 \mathrm{E}-22$ & $5.56 \mathrm{E}-11$ \\
\hline Rural area & $9.07 \mathrm{E}-22$ & $4.33 \mathrm{E}-24$ & $9.02 \mathrm{E}-22$ & $5.37 \mathrm{E}-11$ \\
\hline Small town & $8.83 \mathrm{E}-22$ & $4.44 \mathrm{E}-24$ & $8.78 \mathrm{E}-22$ & $5.31 \mathrm{E}-11$ \\
\hline
\end{tabular}

$\mathrm{b}=$ consistent under Ho and Ha; obtained from xtreg; $\mathrm{B}=$ inconsistent under Ha, efficient under Ho; obtained from xtreg; Test: Ho: difference in coefficients not systematic; chi2 $(16)=(\mathrm{b}-\mathrm{B})^{\prime}\left[\left(\mathrm{V}_{-} \mathrm{b}-\mathrm{V}_{-} \mathrm{B}\right)^{\wedge}(-1)\right](\mathrm{b}-\mathrm{B})=0.00$; Prob $>$ chi2 $=0.045000$ (If this is $<0.05$ (i.e. significant) use fixed effects). Source: authors computation based on SACMEQ survey data, 2000; 2004; 2012. 
Table A11. Fixed effect tests for school characteristics.

\begin{tabular}{|c|c|c|c|c|}
\hline \multirow[b]{2}{*}{ Variables } & \multicolumn{4}{|c|}{ Fixed Effects } \\
\hline & & 2000 & 2004 & 2012 \\
\hline \multirow{4}{*}{ Government Expenditure } & Within & 0.2909 & 1 & 1 \\
\hline & Between & 0.7518 & 1 & 1 \\
\hline & Rho & 0.513 & 0.241 & 0.273 \\
\hline & Within & 0.825 & 1 & 1 \\
\hline \multirow{3}{*}{ School characteristics } & Between & 0.946 & 1 & 1 \\
\hline & Rho & 0.412 & 0.563 & 0.432 \\
\hline & Correlation (u-I,xb) & 0.474 & -0.04 & -0.3 \\
\hline \multirow{4}{*}{ School locations } & Within & 0.546 & 1 & 1 \\
\hline & Between & 0.978 & 1 & 1 \\
\hline & Rho & 0.298 & 0.23 & 0.271 \\
\hline & Correlation (u-I,xb) & 0.723 & -0.321 & 0.147 \\
\hline \multirow{4}{*}{ Distance from Social Amenities } & Within & 0.319 & 1 & 1 \\
\hline & Between & 0.9108 & 1 & 1 \\
\hline & Rho & 0.5211 & 0.2256 & 0.297 \\
\hline & Correlation (u-I,xb) & 0.6589 & -0.3905 & 0.0894 \\
\hline \multirow{4}{*}{ Class types } & Within & 0.362 & 0 & 1 \\
\hline & Between & 0.916 & 1 & 1 \\
\hline & Rho & 0.505 & 0.312 & 0.268 \\
\hline & Correlation $(\mathrm{u}-\mathrm{I}, \mathrm{xb})$ & 0.645 & 0.105 & 0.163 \\
\hline
\end{tabular}

Source: Authors computation based on SACMEQ survey data, 2000; 2004; 2012. 